\title{
PENERAPAN MODEL PEMBELAJARAN COOPERATIVE LEARNING TIPE STAD UNTUK MENINGKATKAN PRESTASI BELAJAR
}

\author{
${ }^{1}$ Sitti Marlina, ${ }^{2}$ Hamran \\ 1, 2Sekolah Tinggi IImu Keguruan dan Pendidikan Pembangunan Indonesia, Indonesia \\ Email: linalangit@gmail.com
}

\begin{abstract}
ABSTRAK
Penelitian ini bertujuan untuk meningkatkan prestasi belajar ekonomi pada siswa SMA Negeri 15 Gowa melalui penerapan model pembelajaran Cooperative Learning tipe Student Team Achievement (STAD). Penelitian tindakan kelas (PTK) ini, meneliti siswa kelas XI IPS SMA Negeri 15 Gowa yang berjumlah 33 orang. Teknik pengumpulan data penelitian adalah observasi, tes, dokumentasi, dan wawancara. Prosedur penelitian meliputi tahap perencanaan, pelaksanaan tindakan, observasi, dan refleksi. Hasil penelitian menunjukkan bahwa melalui penerapan model pembelajaran Cooperative Learning tipe STAD dapat meningkatkan prestasi belajar ekonomi. Pada prestasi belajar siswa, ditunjukkan dengan terjadinya peningkatan ketuntasan secara klasikal dari siklus I sebesar 19,3 \% kemudian pada siklus II mencapai $87.9 \%$ atau 29 dari 33 siswa berhasil mencapai ketuntasan belajar.
\end{abstract}

Kata Kunci : STAD, Prestasi Belajar.

\section{ABSTRACT}

This study aims to improve activities of SMA Negeri 15 Gowa's students in learning achievement at Economy subject through the application of the Student Team Achievement (STAD) Cooperative learning model. This class action research (PTK), discusses about 11th grade IPS students at SMA Negeri 15 Gowa whom helped by 33 people. Technique of collecting data of research are observation, tests, documentation, and interviews. Research procedures, including planning, implementation, observation, and reflection. The results showed that through the application of the STAD type Cooperative Learning model can improve activities in learning activities and learning achievements in Economy subject. Student achievement, it indicated by an increase in completeness classically from the first cycle of $19.3 \%$, then in the second cycle reached $87.9 \%$ or 29 of 33 students succeeded in achieving mastery learning.

Keywords: STAD, Learning Activities, Learning Achievements, STAD.

\section{PENDAHULUAN}

Proses pembelajaran merupakan hal mutlak yang harus dilakukan oleh seorang tenaga pendidik agar tujuan pembelajaran dapat tercapai optimal. Proses pembelajaran akan menentukan tingkat pemahaman siswa dalam menerima materi pelajaran. Namun faktanya, banyak kita jumpai dilapangan yang menunjukkan proses pembelajaran dikelas belum terlaksana maksimal sehingga tingkat pemahaman siswa masih tergolong rendah serta ketercapaian tujuan pelajaran tidak optimal. Proses pembelajaran yang belum efektif tersebut sering kita jumpai karena seorang pendidik 
menyampaikan materi masih kaku sehingga siswa cepat bosan, jenuh dan kehilangan semangat dan motivasi belajar. Model pembelajaran dikatakan relevan jika mampu mengantar siswa mencapai tujuan pendidikan pada umumnya dan tujuan pembelajaran mata pelajaran ekonomi pada khususnya yang diharapkan dapat terlaksana pengajaran di sekolah.

Pembelajaran berlangsung sebagai suatu proses saling mempengaruhi antara guru dan siswa. Dalam hal ini kegiatan yang terjadi adalah guru mengajar dan siswa belajar. Olehnya itu, guru sebagai tenaga pendidik dituntut tidak hanya mengembangkan ilmu pengetahuan, tetapi mampu melaksanakan pembelajaran yang menarik dan bermakna bagi siswanya. Iklim belajar yang kondusif merupakan tulang punggung dan faktor pendorong yang dapat memberikan daya tarik tersendiri bagi proses pembelajaran, sebaliknya iklim belajar yang kurang menyenangkan akan menimbulkan kejenuhan dan rasa bosan.

Berdasarkan pengamatan proses belajar mengajar mata pelajaran Ekonomi di SMA Negeri 15 Gowa saat ini masih menggunakan metode ceramah yang menekankan pada hafalan terhadap konsep dan fakta. Sekolah yang terletak $\pm 96 \mathrm{~km}$ dari Kota Makassar ini merupakan satu-satunya SMA negeri di Kecamatan Bontolempangang yang berada di Desa Paranglompoa. Guru masih sebagai pusat pembelajaran dan bukan siswa yang menjadi subyek pembelajaran. Pembelajaran ini berakibat siswa tidak aktif, kurang berpikir kreatif, dan pembelajaran terkesan membosankan. Kondisi siswa SMA Negeri 15 Gowa yang berasal dari beberapa desa di Kecamatan Bontolempangang dan Kecamatan Bungaya ini memiliki tingkat kecerdasan yang berbeda yang sangat berpengaruh pada pembelajaran dikelas.

Hasil wawancara dengan guru di SMA Negeri 15 Gowa khususnya kelas X, XI, XII, dapat diedentifikasi masalah-masalah yang terjadi dalam pelaksanaan proses belajar mengajar, yakni:

1. Kurangnya partisipasi siswa dalam proses pembelajaran karena guru hanya menggunakan metode ceramah biasa. Guru pernah mencoba menggunakan diskusi kelompok, tetapi hasilnya kurang bagus karena pada waktu presentasi siswa kurang mampu mengungkapkan pendapatnya.

2. Siswa menjadi kurang aktif karena tidak sesuainya metode pembelajaran yang menyebabkan kebosanan dan kejenuhan.

3. Masih banyaknya siswa yang sulit memahami dan menguasai materi. Hal ini berdasarkan keterangan guru dari hasil wawancara yang menyatakan bahwa 
masih banyak siswa yang belum tuntas (nilai ketuntasan yang ditetapkan di sekolah yakni 60).

4. Siswa kurang memanfaatkan sumber belajar yang ada selain catatan yang diberikan oleh guru.

Salah satu model pembelajaran yang dapat mengaktifkan siswa adalah pembelajaran kooperatif. Pembelajaran kooperatif merujuk pada berbagai macam metode pengajaran dimana para siswa bekerja dalam kelompok-kelompok kecil untuk saling membantu sama lain dalam mempelajari materi pelajaran.

Student Team Achievement Division (STAD) merupakan salah satu tipe dari model pembelajaran kooperatif. Pada model ini, pembelajaran dikemas secara berkelompok dengan tingkat prestasi yang berbeda-beda. Dengan demikian, model ini dapat menumbuhkan sikap toleransi atas perbedaan masing-masing individu dalam satu kelompok.

Pada metode STAD ini terdapat beberapa tahap yang harus dilalui selama proses pembelajaran. Pembelajaran kooperatif tipe STAD juga membuat siswa aktif mencari penyelesaian masalah dan mengkomunikasikan pengetahuan yang dimilikinya kepada orang lain, sehingga siswa lebih menguasai materi. Dalam pembelajaran tipe STAD, guru berkeliling untuk membimbing siswa saat belajar kelompok. Hal ini memungkinkan siswa untuk berinteraksi dengan guru. Berdasarkan hal ini, dipandang perlu bagi peneliti untuk melakukan suatu penelitian tindakan kelas guna meningkatkan aktivitas siswa dan prestasi belajar Ekonomi di SMA Negeri 15 Gowa melalui pembelajaran Kooperatif Tipe STAD. Selain itu, penelitian ini diharapkan dapat membantu dosen yang belum memiliki latar belakang penelitian PTK, sebagai cara belajar untuk meningkatkan pengetahuan terkait ini.

Model pembelajaran kooperatif (learning cooperative) memberikan kesempatan kepada siswa untuk bekerja kelompok dalam memecahkan suatu masalah secara bersama-sama. Slavin dalam Isjoni (2010: 15) menyatakan bahwa pembelajaran kooperatif adalah suatu model pembelajaran dimana siswa belajar dan bekerja sama dalam kelompok-kelompok kecil secara kolaboratif yang anggotanya terdiri dari 4-6 orang dengan struktur kelompok heterogen. Jadi dalam model pembelajaran kooperatif, siswa bekerja sama dengan kelompoknya untuk menyelesaikan suatu permasalahan, sehingga siswa akan bertanggung jawab atas belajarnya sendiri dan berusaha menemukan informasi untuk menjawab pertanyaan-pertanyaan yang diberikan pada mereka.

Johnson \& Johnson dalam Trianto (2010: 57) menyatakan bahwa tujuan pokok belajar kooperatif adalah memaksimalkan belajar siswa untuk peningkatan prestasi 
akademik dan pemahaman baik secara individu maupun secara kelompok. Olehnya itu dapat disimpulkan bahwa pembelajaran kooperatif merupakan bentuk pembelajaran dengan cara siswa belajar dan bekerja dalam kelompok dimana anggotanya terdiri dari 4-6 oran dengan struktur kelompok yang heterogen.

STAD merupakan salah satu metode pembelajaran kooperatif yang paling sederhana dan merupakan model yang paling baik untuk permulaan bagi para guru yang baru menggunakan pendekatan kooperatif. Menurut Slavin (2009: 143) Model Pembelajaran Kooperatif Tipe STAD adalah bentuk pembelajaran kooperatif yang paling banyak diaplikasikan, telah digunakan dalam mata pelajaran Matematika, Seni Bahasa, IImu Sosial, dan IImu Pengetahuan Alam. STAD merupakan salah satu metode pembelajaran kooperatif yang paling sederhana, dan model yang paling baik untuk permulaan bagi guru yang baru menggunakan pendekatan kooperatif.

Isjoni (2010: 74-95) mengungkapkan bahwa pembelajaran kooperatif tipe STAD merupakan salah satu tipe kooperatif yang menekankan pembelajaran pada adanya aktivitas dan interaksi diantara siswa untuk saling memotivasi, serta membantu dalam menguasai materi pelajaran guna mencapai prestasi yang maksimal.

Menurut Trianto (2010:68), Model Pembelajaran Kooperatif Tipe STAD adalah merupakan salah satu tipe pembelajaran kooperatif dengan menggunakan kelompokkelompok kecil dengan jumlah anggota tiap kelompok 4-5 orang siswa secara heterogen. Diawali dengan penyampaian tujuan pembelajaran, penyampaian materi, kegiatan kelompok, kuis, dan penghargaan kelompok.

Hidayat (2019: 142) mengungkapkan langkah-langkah yang perlu dilakukan untuk menerapkan model pembelajaran Cooperativ Learning Tipe STAD adalah sebagai berikut:

1) Pendidik menyampaikan materi pembelajaran sesuai kompetensi dasar yang akan dicapai. Pendidik dapat menggunakan berbagai pilihan metode penyampaian.

2) Pendidik memberikan tes/kuis kepada setiap peserta didik secara individual sehingga akan diperoleh nilai awal kemampuan peserta didik.

3) Pendidik membentuk beberapa kelompok. Setiap kelompok terdiri atas 4-5 anggota yang mempunyai kemampuan akademik berbeda-beda (tinggi, sedang, dan rendah). Bila memungkinkan anggota kelompok bisa berasal dari budaya atau suku yang berbeda pula serta memperhatikan kesetaraan gender.

4) Pendidik memberikan tugas kepada kelompok berkaitan dengan materi, mendiskusikannya bersama-sama, saling membantu antar sesama anggota, serta membahas jawaban dari tugas yang telah diberikan oleh pendidik. 
5) Pendidik memberikan tugas tes kepada setiap peserta didik secara individual.

6) Pendidik memfasilitasi peserta didik dalam membuat rangkuman, mengarahkan, serta memberikan penegasan materi pembelajaran yang telah dipelajari.

7) Pendidik memberi penghargaan kepada kelompok berdasarkan perolehan nilai peningkatan hasil belajar individual dari nilai awal kenilai kuis berikutnya.

Metode STAD membutuhkan persiapan yakni:

1) Materi

Cukup mudah membuat materi. Cukup dengan membuat sebuah lembarkegiatan, sebuah lembar jawaban, dan sebuah kuis untuk setiap uni yang direncanakan untuk diajarkan. Tiap unit harus terdiri dari tiga sampai lima intruksi.

2) Membagi siswa kedalam tim.

Langkah pertama adalah menyusun peringkat siswa, kemudian menentukan jumlah tim, lalu membaginya kedalam tim yang terdiri atas level yang kinerjanya berkisar dari rendah, sedang, dan tinggi. Level kinerja yang sedang dari semua tim yang ada dikelas hendaknya setara/sama. Terakhir adalah mengisi nama-nama siswa dari tiap tim ke dalam lembar rangkuman.

3) Menentukan skor awal pertama.

Skor awal mewakili skor rata-rata siswa pada kuis-kuis sebelumnya. Apabila STAD dimulai setelah tiga kali atau lebih kuis, gunakan rata-rata skor kuis siswa sebagai skor awal. Atau jika tidak, gunakan hasil nilai terakhir siswa dari tahun lalu.

4) Membangun tim.

Sebelum memulai program pembeajaran kooperatif apapun, akan sangat baik jika memulai dengan satu atau lebih latihan pembentukan tim sekadar untuk memberi kesempatan kepada anggota tim untuk melakukan sesuatu yang mengasyikkan dan untuk saling mengenal satu sama lain. Tiap pelajaran dalam STAD dimulai dengan presentasi pelajaran tersebut di dalam kelas. Presetasi tersebut haruslah mencakup pembukaan, pengembangan, dan pengarahan-praktis tiap komponen dari keseluruhan pelajaran, kegiatan-kegiatan tim dan kuisnya mencakup latihan dan penilaian yang independen, secara berturut-turut.

Pembelajaran adalah integrasi dari proses dan produk. Hal ini mengindikasikan bahwa proses pembelajaran yang baik akan berdampak baik pula pada produk atau hasil dari pembelajaran tersebut. Proses pembelajaran tidak terlepas dari peran pendidik dan perseta didik. Komunikasi yang lancar antar keduanya akan membuat pembelajaran lebih hidup. Salah satu hal yang berpengaruh pada proses pembelajaran adalah aktifitas belajar peserta didik. 
Proses pembelajaran dikatakan efektif bila peserta didik secara aktif ikut terlibat langsung dalam pengorganisasian dan penemuan informasi (pengetahuan), sehingga mereka tidak hanya menerima secara pasif pengetahuan yang diberikan oleh guru. Dalam proses belajar mengajar tugas guru adalah mengembangkan dan menyediakan kondisi agar peserta didik dapat mengembangkan bakat dan potensinya.

Prestasi adalah hasil yang telah dicapai (dilakukan, dikerjakan, dan sebagainya). Kata prestasi berasal dari Bahasa Belanda "Prestasic" yang berarti hasil usaha. Selanjutnya untuk memahami tentang belajar dikemukakan beberapa pengertian berikut:

Menurut Slameto (2010) dalam bukunya Belajar dan faktor-faktor yang mempengaruhinya bahwa belajar adalah suatu usaha yang dilakukan oleh seseorang untuk memperoleh suatu perubahan tingkah laku yang baru secara keseluruhan, sebagai hasil pengalamannya sendiri dalam interaksi dengan lingkungannya. Dalam kamus Bahasa Indonesia, prestasi belajar didefinisikan sebagai hasil penilaian yang diperoleh dari kegiatan persekolahan yang bersifat kognitif dan biasanya ditentukan melalui pengukuran dan penilaian.

Prestasi belajar tidak dapat dipisahkan dari kegiatan belajar, karena belajar merupakan suatu proses, sedangkan prestasi belajar adalah hasil dari proses pembelajaran tersebut. Bagi seorang anak, belajar merupakan suatu kewajiban. Berhasil atau tidaknya seorang anak dalam pendidikan tergantung pada proses belajar yang dialami oleh anak tersebut. Prestasi belajar dapat dipengaruhi beberapa faktor dalam proses kegiatan pembelajaran di sekolah, antara lain: siswa itu sendiri, guru dan personal lainnya, bahan pengajaran, metode pengajar dan sistem evaluasi, sarana penunjang, hingga sistem administrasi.

\section{METODE PENELITIAN}

Penelitian ini merupakan penelitian tindakan kelas (Classroom Action Research) yang merupakan intervensi praktik dunia nyata yang ditujukan untuk meningkatkan situasi praktis (Situmorang, 2019:4). Variabel-variabel yang diselidiki dalam penelitian ini adalah Model pembelajaran Kooperatif Tipe Student Teams Achievement Divisions (STAD) dan Prestasi belajar.

Populasi dalam penelitian ini adalah siswa SMA Negeri 15 Gowa tahun ajaran 2018/2019. Subyek penelitian adalah siswa jurusan IPS SMA Negeri 15 Gowa sebanyak 33 orang kelas IX. Jenis data pada penelitian ini adalah kuantiatif dan kualitatif. Sumber sata diperoleh dari guru dan siswa yakni melalui observasi dan 
wawancara. Teknik pengumpulan data dalam penelitian ini melalui metode observasi, tes, dokumentasi, dan wawancara sebagai uji validitas data. Teknik analisis data yang digunakan adalah dengan menggunakan teknik analisis deskriptif kuantitatif berupa data prestasi belajar, dan hasil observasi aktivitas belajar yang dipaparkan dalam kalimat.

\section{HASIL DAN PEMBAHASAN}

1. Hasil Observasi Aktivitas Belajar Siswa

Hasil analisis data menunjukkan keberhasilan Prestasi Belajar dari tindakan yang diberikan dapat dilihat dari nilai siswa yaitu pre-test dan post-test. Peningkatan Hasil Belajar Ekonomi Kelas XI IPS SMA NEgeri 15 Gowa dapat dilihat pada tabel berikut ini:

Tabel.4.8. Hasil Pre Test dan Post Test

\begin{tabular}{|c|c|c|c|c|c|c|c|c|}
\hline \multirow[t]{2}{*}{ Siklus } & \multirow[t]{2}{*}{$\begin{array}{l}\text { Jenis } \\
\text { Tes }\end{array}$} & \multirow[t]{2}{*}{$\begin{array}{l}\text { Jml } \\
\text { Siswa }\end{array}$} & \multirow[t]{2}{*}{$\begin{array}{l}\text { Nilai } \\
\text { Terendah }\end{array}$} & \multirow[t]{2}{*}{$\begin{array}{l}\text { Nilai } \\
\text { Tertinggi }\end{array}$} & \multicolumn{2}{|c|}{$\begin{array}{c}\text { Jumlah } \\
\text { Siswa }\end{array}$} & \multicolumn{2}{|c|}{ Persentase } \\
\hline & & & & & $<75$ & $\geq 75$ & $<75$ & $\geq 75$ \\
\hline $\mathrm{I}$ & Pre Test & 29 & 45 & 65 & 27 & 2 & 93.1 & 6.9 \\
\hline & $\begin{array}{l}\text { Post } \\
\text { Test }\end{array}$ & 31 & 50 & 90 & 25 & 6 & 80.7 & 19.3 \\
\hline II & $\begin{array}{l}\text { Pre Test } \\
\text { Post } \\
\text { Test }\end{array}$ & $\begin{array}{l}31 \\
33\end{array}$ & $\begin{array}{l}35 \\
45\end{array}$ & $\begin{array}{l}85 \\
100\end{array}$ & $\begin{array}{l}19 \\
4\end{array}$ & $\begin{array}{l}12 \\
29\end{array}$ & $\begin{array}{l}61.2 \\
12.1\end{array}$ & $\begin{array}{l}38.8 \\
87.9\end{array}$ \\
\hline
\end{tabular}

Sedangkan untuk lebih jelasnya peningkatan persentase siswa yang sudah mencapai KKM 75 pada siklus I dan siklus II dapat dilihat pada gambar berikut :

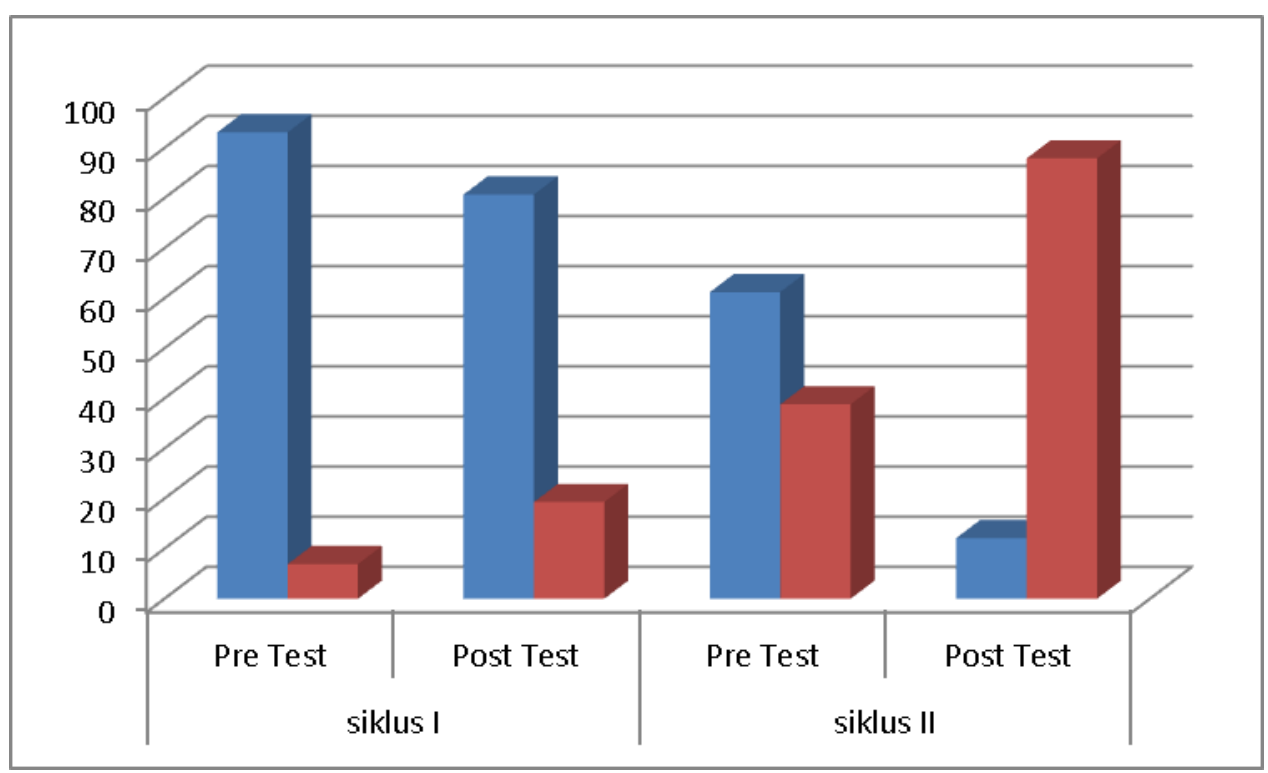

Gambar 4.1. Diagram Batang Persentase Pencapaian KKM

Berdasarkan data Tabel 4.8 dan Gambar 4.1 yang disajikan, Prestasi Belajar Ekonomi siswa dari tes siklus I ke tes siklus II mencapai indikator keberhasilan yang 
diharapkan dalam penelitian ini yakni $\geq 85 \%$, dimana persentase ketuntasan klasikal yang diperoleh sebesar $87,9 \%$ atau sebanyak 29 orang siswa mencapai ketuntasan dari 33 jumlah siswa.

\section{KESIMPULAN}

Berdasarkan analisis dan pembahasan penelitian, maka dapat disimpulkan bahwa Penerapan Model Pembelajaran Cooperative Learning Tipe STAD dapat meningkatkan Prestasi Belajar ekonomi siswa. Hal ini didukung dengan hasil penelitian yang diperoleh bahwa prestasi Belajar Ekonomi siswa Kelas XI IPS SMA Negeri 15 Gowa dari tes siklus I ke tes siklus II sudah mencapai keberhasilan pembelajaran yang diharapkan, dimana Siswa yang mencapai ketuntasan (KKM) yaitu terjadi peningkatan dari siklus I sebesar 19,3\% meningkat menjadi 87,9 \% atau sebanyak 29 orang siswa mencapai ketuntasan dari 33 jumlah siswa.

Penelitian ini memberikan gambaran yang jelas bahwa keberhasilan suatu pembelajaran tergantung pada beberapa faktor yang saling berkaitan dengan yang lain dengan melihat indikator proses. Faktor-faktor tersebut berasal dari pihak guru dalam mengelola kelas, memberikan materi, dan menerapkan model pembelajaran tersebut. Faktor dari peserta didik sendiri antara lain minat belajar, dan keaktifan dalam mengikuti proses pembelajaran. Faktor tersebut harus diupayakan secara maksimal agar proses pembelajaran dapat berjalan dengan lancar, kondusif, efektif, dan efisien.

\section{DAFTAR PUSTAKA}

Hidayat, Isnu. 2019. 50 Strategi Pembelajaran Populer (Kumpulan Lengkap Teori dan Aplikasi Pembelajaran Masa Kini). Yogyakarta: Diva Press

Isjoni. 2010. Pembelajaran Kooperatif: Meningkatkan Kecerdasan antar Peserta Didik. Yogyakarta: Pustaka Belajar.

Situmorang, Manihar. 2019. Penelitian Tindakan Kelas (Strateg Menulis Proposal, Laporan, dan Artikel IImiah). Depok: PT RajaGrafindo Persada.

Slameto. 2010. Belajar dan Faktor yang Mempengaruhinya. Jakarta: Rineka Cipta.

Slavin, R.E. 2005. Cooperative Learning teori, Riset, dan Praktik. Bandung: Nusa Media.

Trianto. 2010. Model Pembelajaran Terpadu: Konsep, Strategi, dan Implementasinya dalam Kurikulum Tingkat Satuan Pendidikan (KTSP). Bumi Aksara. Jakarta 